\title{
Bilingual Education Program: Teachers' and Students' Perspectives and Challenges
}

\author{
Nurul Fauziah, Soni Mirizon*, Sary Silvhiany \\ Graduate School of English Education, Sriwijaya University, Indonesia \\ *Corresponding email: smirizon@unsri.ac.id
}

Received: 05 July 2021

Accepted: 16 August 2021

Published: 23 August 2021

Abstract: Bilingual Education Program: Teachers' and Students' Perspectives and Challenges. Objectives: The objectives of this study were to investigate the teachers' and students' perspectives of bilingual education program and the challenges faced. Methods: In this qualitative case study, the participants were the science teachers and the tenth-graders of the program. The data were gathered using interviews and observations and were analyzed by organizing and planning the results, paying attention to data, coding the data, generating the description and themes, and reflecting descriptions and themes. Findings: First, all science teachers and most students had positive perspectives and admitted the benefits of the program. Second, all the teachers and students faced challenges during the implementation of the program. Conclusion: All teachers and most students positively perceived bilingual education program. However, their positivity could not free them from facing challenges. Therefore, some improvements are required to enhance the program.

Keywords: bilingual education, teachers, students, perspectives, challenges

Abstrak: Program Pendidikan Dwibahasa: Perspektif dan Tantangan Guru dan Siswa. Tujuan: Penelitian ini bertujuan untuk menginvestigasi perspektif guru dan siswa terhadap program pendidikan dwibahasa dan tantangan yang mereka hadapi. Metode: Dalam penelitian kualitatif studi kasus ini, pesertanya adalah guru IPA dan siswa kelas sepuluh program tersebut. Pengumpulan data dilakukan dengan wawancara dan observasi serta dianalisis dengan mengorganisasikan dan merencanakan hasil, memperhatikan data, mengkodekan data, membangkitkan deskripsi dan tema, serta merefleksikan deskripsi dan tema. Temuan: Pertama, semua guru IPA dan sebagian besar siswa memiliki perspektif positif dan mengakui manfaat program. Kedua, semua guru dan siswa menghadapi tantangan selama pelaksanaan program. Kesimpulan: Semua guru dan sebagian besar siswa memandang positif program pendidikan bilingual. Namun, kepositifan mereka tidak bisa membebaskan mereka dari menghadapi tantangan. Sehingga, diperlukan perbaikan untuk menyempurnakan program tersebut.

Kata kunci: pendidikan dwibahasa, guru, siswa, perspektif, tantangan

\section{To cite this article:}

Fauziah, N., Mirizon, S., \& Silvhiani, S. (2021). Bilingual Education Program: Teachers' and Students' Perspectives and Challenges. Jurnal Pendidikan Progresif, 11(2), 219-234. doi: 10.23960/ jpp.v11.i2.202107. 


\section{INTRODUCTION}

Mastering more than one language has become a trend nowadays. In this globalization era, people are required to master more than one language in order to be able to communicate with other people from different countries. To communicate with people from other countries, someone cannot use their mother tongue or their national language. Therefore, mastering a foreign or an international language such as English is essential. English is one of the widely used international languages spoken by people worldwide. English plays a vital role in international communication. Rao (2019) argues that English holds an exclusive position because it is the most commonly used language. Moreover, it develops as a leading global language in all fields. Therefore, mastering English in addition to mastering mother tongue or the national language helps someone to communicate with people from different regions.

Someone who speaks two languages is known as bilingual. Baker (2001) defines bilingualism as the implementation of two languages in an individual. Bilingualism has become a concern of government from many countries for years. There has been much discussion about bilingualism and efforts made to make people bilingual. One of the popular programs implemented in many countries around the world concerning bilingualism is bilingual education. Bilingual education refers to utilize two languages in an educational environment. Bilingual education varies from other types of language education where content subject material and language acquisition are integrated, ensuring that two languages are used as teaching tools (Garcia \& Wei, 2015; Wright, Boun, \& Garcia, 2015). Bilingual education discussed in this study was defined as the use of two languages in two different curricula in the teaching and learning process. Science subjects such as chemistry, physics, and biology were taught in English and
Indonesian, while other subjects were taught in Indonesian.

Bilingualism and bilingual education have always been hot topics to discuss. Baker (2001) points out that bilingual education has always been a contentious topic in the education field worldwide for many decades. No wonder there are many studies conducted in this area. Taheri and Heidar (2014) report that bilingual education is one of the common and debatable initiatives to address the lack of understanding of foreign languages.

Governments in many countries try to boost their people's performance in mastering English by providing bilingual education program. Countries such as China, Spain, and Turkey have implemented bilingual education program to reach that goal. In the same concern, Indonesian government also adopted this effort to improve Indonesian people foreign language mastery in order not to be left behind in the global competition. Therefore, one way to improve Indonesian citizens' foreign language competence is by implementing bilingual education program in Indonesian schools.

In Indonesia, bilingual education was initially formally designed in formal education through a program called Pioneering International Standard Schools [Rintisan Sekolah Bertaraf Internasional, RSBI]. The Indonesian government tried to develop schools encouraging the development of education through $R S B I$. This idea was based on the act of the Republic of Indonesia number 20, the year 2003-chapter 14 articles 50 section 3 . It was written that the government and local state coordinate at least one education unit to establish international academic standards. Unfortunately, it was officially terminated due to several reasons.

However, the nature of bilingual education program with different forms and names remains. In the last three years, the Ministry of Education and Culture has initiated a new program into 
public senior high schools in Indonesia through the Cambridge curriculum. Schools are allowed to adopt Cambridge curriculum in addition to 2013 curriculum (dual curriculum). The implementation of the Cambridge Curriculum requires students to learn content subjects in English as the language of instruction.

Unlike RSBI, bilingual education program of dual curriculum is the local government program to facilitate students who have good English ability and want to gain extra credentials from international institutions. Some public schools in Palembang, such as SMAN 1, SMAN 17, and SMAN Sumsel, are appointed to implement the Cambridge curriculum. English is used as one of the languages of instruction for teaching science and math subjects. In these schools, not all classes implement the Cambridge curriculum. There are some special classes designed to use the Cambridge curriculum and the 2013 curriculum. Among the three senior high schools, SMAN Sumsel was the first school which ran this program and became the center of the program. In 2018, the South Sumatera governor appointed two other schools to take part in running the program.

Previous studies reported the implementation of bilingual education in some countries. It was found that students' English language background and exposure were likely influenced their participation in a bilingual education program. Those who had more exposure to English had more positive perceptions than those who did not. It was also found that students believed English they learned in the program might significantly affect their future and opportunities. Furthermore, the implementation of English as media of instructions in the bilingual program increased students' English proficiency, although sometimes, their mastery of the content subject, the key aim of the bilingual course, was not achieved. It was also apparent that limited English proficiency was the critical challenge found in encouraging student achievement. Low levels of English skills hindered students from understanding essential English teaching affecting their mastery of content subject knowledge. It hindered the teachers from explaining well, so the goal of teaching and learning cannot be fulfilled. (Fernandez-Costales, 2017; Fitriati, 2015; Jurado \& Garcia, 2018; Lee, 2006; Li, 2018; Li \& Wang, 2010; Ozfidan, Burlbaw \& Kuo, 2016; Putri, 2010; Taheri \& Heidar, 2014; Tina, Zaim \& Syafei, 2013; Tong \& Shi, 2012; Surdyanto, 2016).

Other previous studies in Indonesia context, such as in the former RSBI school program, showed some failures due to some factors. Fitriati (2015) discovered that English became a heavy burden that raised teachers' tension, reinforced a sense of uneasiness, and decreased confidence. Teachers admitted that it was hard to teach mathematics and science subjects in English without prior training in English as a medium instruction context. Besides, Putri (2010) found the benefits and drawbacks of bilingual education program. In the field of science subjects, bilingual education program enabled students to learn English. Compared to those who were in regular school, they had greater English mastery. Besides, bilingual education program enhanced the creativity of the teachers. However, it made the students felt unsure and confused about the lesson because of their lack of English mastery and the teacher's lack of English proficiency.

Findings from those previous studies played an essential role in this current study. There was a gap that the writer found regarding the implementation of bilingual education program in a formal school. Among those studies, each focused on one problem to investigate. In China, the researcher merely investigated the effectiveness of bilingual education program at university. A study from Southern California discussed students' attitudes, perceptions, and views on bilingual education program. Another 
difference is concerning the region where the research was conducted. Some studies were conducted beyond Indonesia. Moreover, studies conducted in Indonesia were done in different regions. There were hardly found any studies concerning bilingual education program conducted in Palembang city, especially the one in dual curriculum. Therefore, the writer was challenged to investigate teachers' and students' perspectives of bilingual education program and the challenges they faced. This study was a part of a bigger study investigating the implementation of bilingual education program conducted in one public senior high school in Palembang. This article was focused only on teachers' and students' perspectives of bilingual education program and the challenges they faced.

Concerning the implementation a bilingual education program in a school, it is essential to know the teachers' and students' and perspectives of the program they participated in. Lotherington (2004) states students' perspectives about the program they are involved and toward the languages they are learning influence the learners' progress and success in being bilingual. Therefore, students' perspectives of the program they participated in play a vital role in supporting their success in joining the program. Besides, teachers' perpectives of bilingual education will also influence how they behave in their teaching and learning. Their attitudes toward the program play a significant role as they are the ones that run the class. In line with that, Richards and Lockhart (1994) state teachers need to have high enthusiasm. They have to enjoy the class because their way of portraying themselves influenced the way they teach their students.

The framework used in this study is drawn upon bilingual education proposed by Baker (2001) called mainstream education with foreign language teaching. Baker (2001) formulates mainstream education with foreign language teaching involves lessons in a foreign language as a curriculum subject. It is a process of teaching a foreign language to non-language lessons. Besides, this study is also drawn upon the attribution theory by Heider (1958). He proposes attribution theory as "naive psychology" to better understand other people's attitudes and perceptions by explaining how individuals justify their behavior lightly. In this study, the writers focused on understanding teachers' and students' perspectives of the program. In specific, the objectives of this study were to find out: (1) teachers' and students' perspectives regarding the implementation of bilingual education program of dual curriculum in a public senior high school in Palembang, (2) the challenges they faced in teaching and learning content subjects in a bilingual education program of dual curriculum at the school.

\section{METHODS}

This study applied a qualitative research approach. Tracy (2013) asserts that qualitative study as a method of examining, exploring, and comprehending the significance ascribed to a social or human issue. This qualitative study was categorized as a case study. Creswell and Creswell (2018) point out that a case study is a form of investigation used in various fields. A qualitative case study design used in this study was employed to investigate a phenomenon that occurred. It focused more on the in-depth examination of teachers' and students' perspectives and challenges of the implementation of bilingual education program of dual curriculum in a public senior high school. The writers focused on a detailed case study of an event, actions, process, one or more individuals. Besides, the research questions of this study necessitated answers be sought via a case study to obtain a complete explanation of the phenomenon.

The study was carried out at one public 
senior high school in Palembang, accredited A. This school offered bilingual education program of dual curriculum that implemented teaching and learning processes using English and Indonesian in math and science subjects. The participants of this study were the tenth-graders from X.1 and X.2 of bilingual education program of dual curriculum. They were selected because they experienced more than six months of learning in the program. Besides, they did not join many additional courses out of their learning time at school like what the eleventh and twelfth graders did. There were 62 students from the two classes. Among those, eight students were interviewed and became the focused of the study. They were chosen based on the recommendation from science teachers and homeroom teachers with the category of high achieving students and underachieving students in the class. In addition, three Cambridge curriculum teachers were also involved as the participants. Of the three teachers, each was biology, physics, and chemistry teachers. They were chosen since they taught bilingual education program of dual curriculum classes from the beginning.

The data of the study were collected through interviews and observations. Semistructured interviews were conducted for about 40-90 minutes twice per participant. There were eight students, three teachers, and one coordinator interviewed. Furthermore, observations were done depending on the completion of the teaching time allocated in one basic competence stated in the curriculum. Thus, there were four observations conducted for each subject in both classes in the regular teaching time. There was also one observation in the additional class for biology and physics. In total, there were 14 observations conducted for the three subjects. All teaching and learning processes were conducted through online meetings. Therefore, most data collections were gathered via online, such as through zoom meeting, google meet, line video calls, line chat, and WhatsApp chat messenger. All the interviews with the sample students were conducted online since they were not allowed to go to school. Meanwhile, the interviews with the teachers were done both online and offline. The first interview was conducted offline at the school, while the second interview was conducted online using zoom meeting calls.

In analyzing the data, the overview of the data analysis process was used (Creswell \& Creswell, 2018). First, the raw data was prepared (transcribing the interview documents, typing up field notes, and sorting observation grid). Second, more attention was paid to the detail of the data to grasp the concept and intention of what the participants said and did. The third was to code all information to get the category and theme the data using in vivo coding. The fourth was generating the themes and descriptions based on the coding and categories. Before going to the last step, the writers did the triangulation to verify the validity and the accuracy of the results. The writers also conducted the member checking technique since it helped ensure whether the data were correct and avoided misinterpretation in analyzing the data. Therefore, the writers did follow-up interviews with all the samples. Reflecting descriptions and themes to shape data was the final stage, which involved writing a narrative passage to articulate the findings.

\section{RESULTS AND DISCUSSION Teachers' and Students' Perspectives of Bilingual Education Program of Dual Curriculum}

The interview was used as the primary source of collecting the data to answer the first objective of the study: the students' and teachers' perspectives regarding the implementation of bilingual education program of dual curriculum at the school. In addition, observation was 
conducted to confirm the interview data.

\section{Teachers' Perspective on Bilingual Education Program of Dual Curriculum}

Teachers' perspectives on the bilingual education program of dual curriculum influenced how they behaved in their teaching and learning processes. Luckily, all science teachers in this study had positive perspectives of the implementation of the program at the school. The interview data showed some factors that influenced their perspective. First, students got the benefits from the program, such as it improved their English skills, improved their comprehension skill, and it made them able to join and win international competitions such as English speech, English debate, international science olympiad. Second, teachers also gained some benefits from the program, such as it improved their English competence, they became more confident using English in teaching science subjects. Third, both teachers and students could learn IGCSE Cambridge materials which were more practical than 2013 curriculum materials.

In this study, the Cambridge science teachers argued that the bilingual education program of dual curriculum benefited them and their students. The program gave some benefits to the teachers. They would be a better teacher with a global perspective, improving the way they teach, their English ability improved, and become more confident in teaching science content using English. The followings are excerpts from interviews that support this information.

My perspective is very positive. How can students do science research if they don't understand the context of science and the sources are in English? Then when presenting their ideas at the international event, they must use English. The only way to help is by conducting this program. When they are used to speak in English, they dare to talk if there is an opportunity for an international event. Luckily, our students did very well. We have won dozens of medals during the third year of the Cambridge class. We are also representatives of Indonesia in foreign countries. (P1 Teacher)

Yes, of course, absolutely positive. We can say that IGCSE is more practical. We cannot learn just theory in our life. We should also learn about the practical, so it really needed them to experience the environment and the English. So, I have a positive perspective. It will help them improve themselves, encourage them to be better people, and motivate them to become more confident. Absolutely, the student is going to get the benefit from the program. You see that my English is improving. It really helps me to improve myself. I can improve the way I'm teaching, my English as well. I become more confident. I even learn about new words or vocabulary that are not used in daily life. (P2 Teacher)

Of course, I have a positive side. I believe that if the students can learn the topics in the dual curriculum, their capabilities are the same as those in other countries because they also face the Cambridge exam. It's really good as the representation of education of Indonesia. Another reason is it also influences the teachers to be better teachers with a global perspective. That's important because we can see the other educations and learn it to apply it in our area. It also improves my English ability. The students are also more 
confident to speak in front of many people. (P3 Teacher)

Similarly, Sudiatmika, Nitiasih, and Suarnajaya (2017) found that the science teachers had a favorable opinion of English use as a language of instruction in science classrooms. In line with this, Noviani, Dahnilsya, and Novitri (2018) discovered a high degree of satisfaction in teachers' mindsets and understanding of bilingual education. The outcome showed that after teaching, the English proficiency of teachers had increased. The results showed the success of the program in improving teachers' English proficiency.

Besides, the teachers' positive perspectives were also triggered as they thought that this program also benefited students. Joining the program made students understood the context of science learning in English, improved themselves to be better students, and became more confident to speak English in front of others. Furthermore, the program also helped students got more chances to join any international competitions and win medals. In line with this, Taheri and Heidar (2014) reported an improvement in their students' language achievement after participating in a bilingual class.

The results of observation proved the teachers' positive perspectives. It could be seen that the teachers were really enthusiastic in teaching the science concepts to the students. They enjoyed interacting with the students using dual language. One teacher even was really enthusiastic about using English fully when interacting with the students. Other teachers also showed the same thing even though they combined the use of language. Even though they were not English teachers nor English native speakers, they showed their best in teaching.

In short, all the teachers in this study shared positive perspectives toward the implementation of bilingual education program of dual curriculum in the school. They believed that the implementation of the program gave advantages to the teachers, students, and the governments.

\section{Students' Perspectives on the Bilingual Education Program of Dual Curriculum}

The interview data showed that most students in this study had a positive perspective towards the implementation of bilingual education program of dual curriculum for some reasons. First, they had a good opportunity to learn to practice English that is very important for the future. Second, the program helped them broaden global horizons through course content learned from two curricula. Third, the program offered more new experiences and new ways of learning. Last, the students got a Cambridge certificate to enroll in the university overseas. To support the data above, the followings are the excerpts from the interview with the students that showed how the student believed in the significant impact of the program on their life now and in the future.

It's more positive. There are enjoyment and difficulties in joining this program. For a bright future, I'm more familiar with English, the more knowledge I have. So it's not only in K13 that I got but also IGCSE material. So, the broader insight I have. (P2 Student)

It's more positive because by learning two curricula, we gain more knowledge and experience. My personal opinion about this program is positive. However, I still face some obstacles. The main reason I like this program is that it uses English. It also adds a lot of vocabulary. (P4 Student)

This program is positive. The first is to train our skills as Indonesians to learn 
a foreign language. The second one adds insight to be more open-minded. Since we implement two curricula, we are from developing countries, so we need lessons from advanced countries to broaden our horizons. Perhaps learning in the Cambridge curriculum is helpful in the future. (P5 Student)

I think my perspective is really positive. The first is because English is an international language. English as an international language in the future will be very impactful, beneficial. The second one is it turned out to be fun learning in two languages that mixed. It's also fun because of the experience, atmosphere, and new ways of learning. I also get material from abroad.(P6 Student)

It's more positive. Because many universities use English, or if it is possible to go abroad, it is more beneficial because it has been applied now. We can also take the Cambridge exam and get a certificate for our future education. (P7 Student)

It's positive. This program is good because people have to be brave to get out of their comfort zone, and English is essential because all things are in English. So if we don't speak English, we will be very lost. This program also helps broaden the horizons of English. So we can compete in the world with global insight. (P8 Student)

It can be seen from the data above that the students admitted their interest and expectation for the implementation of bilingual education program of dual curriculum in their school.
However, data from the interview also showed that few students had a negative perspective on the program for some reasons. First, they thought that the program was not much different from the mainstream class. Second, the class was not interactive, and the teaching and learning process did not dominantly use English as the language of instruction; more students used Indonesian in the class. To support this data, below are the excerpts of interviews with the students.

The program is not effective. I don't think there's much difference with the regular class. There is no more distinguishing variation. The expectation is interactive, and we have a conversation in English fully. However, we still talk to each other in our language. Besides, we need to learn Indonesian first before we can understand English. I want the teacher to use full or dominant English, a lot of interaction in English. (PI Student)

I think it tends to be negative. While interacting with each other, we mostly use Indonesian. So, it's just like a regular class. (P3 Student)

The interview quotes above showed that few students still tended to have negative perspectives since the program did not fulfill their expectations. From the data above, the findings of this study showed that most students had a positive perspective of bilingual education program of dual curriculum. Many factors influenced the students' positive perspectives. In this study, the students admitted that this bilingual education program of dual curriculum used English as the language of instruction besides Indonesian. Mastering English as an international language is essential since it could contribute to someone's future life brighter. In accordance with this, 
Ozfidan et al. (2016) pointed out that bilingual education program would provide employment prospects for potential jobs for students. In addition, bilingual education program trained students' English skills to be better and improved students' English skills. Learning two languages is fun and expands knowledge since students understand both the national and Cambridge curriculum.

Besides, after studying for about a year, the students can take the Cambridge exam and get a Cambridge certificate which is very useful to pursue a higher degree overseas. Students' promising future influences their perspectives. In line with this, Jurado and García (2018) discovered that students showed positive perceptions and enthusiasm for science topics in the bilingual program because of the potential opportunities the program offered. Furthermore, Surdyanto (2016) revealed students' prior exposure to a foreign language was related to their potential preference. Few students had positive perceptions since they had English course backgrounds. It could answer why almost all samples of this study had positive perspectives of the bilingual program.

The results of observation showed that many students seemed excited in joining the classroom teaching. The students enjoyed learning two curricula using two languages. It could be seen from the observation that most students joined the zoom meetings and responded to the dual curricula teaching topics. However, it was quite rare for the students to respond in English. They were very excited when the teachers taught the Cambridge curriculum topics and reminded them about the IGCSE final exam that they will have soon. Still, it seemed hard for them to communicate in English.

In conclusion, most students have positive perspectives toward bilingual education program of dual curriculum. They believed this program benefits them now and in the future. They did expect this program to help brighten their future education and life. They relied on this program to more expansive their knowledge and improved their English. Even so, they still faced some obstacles that made them a bit inactive in the classroom interaction. Besides, few students had negative perspectives since the program did not fulfill their expectations.

In line with the positive perspectives described above, the teachers and students admitted that bilingual education program of dual curriculum had many strengths that influenced their positive perspectives. Based on the interview data, some strengths of the program are: first, bilingual education program of dual curriculum was a special program, providing additional classes to give extra lessons. Second, the program promoted English from a foreign to a second language. Third, grade 10 students learned the learning materials of grades 11 and 12 earlier in the Cambridge curriculum. Fourth, the students had global perspectives about education, especially for learning science in English. Last, the students could get a certificate from Cambridge; it has more value if they want to pursue further study in Indonesia or overseas. To support the data above, the interview statements from the teachers and students are shown below.

Since we use a foreign language, students automatically open their minds. They prefer to go to foreign websites. Previously, English was a foreign language for them, but it can be a second language since it is applied here. If it's not covid, the students are ready to go abroad. (P1 Teacher)
Most of the students in the Cambridge curriculum join some competitions, and win medals. They do not only have intelligence in some subjects, but they 
also presented the idea in English. (P2 Teacher)

Cambridge classes in this school are one of the best classes, the special program. This program provides additional classes. The program results in outstanding students competing worldwide concerning their English, maths, and science concepts. The students also have good global perspectives abouteducation, especially for learning science and English. (P3 Teacher)

We can feel what it's like to be in a bilingual class. We can also experience richer knowledge because we study the national and the Cambridge curricula and explore many things. (P1 Student)

The program makes us more accustomed to English, increases our knowledge of English, and adds other new vocabularies. We can also get a certificate from Cambridge to help us later. (P2 Student)

Improve English skills. (P3 Student)

Open a path to study abroad, and a means to experience the feeling of studying abroad. (P4 Student)

It's more about practicing our Englishspeaking skills and increasing our knowledge to be the same as international and private school students. Then, bilingual education in private schools is expensive while we have a lower payment and get the same thing. So, it's better. (P5 Student)
The most significant strength is the teachers. Their explanations are easy to understand. (P6 Student)

Some lessons are taught in K13 when we are in grades 11 and 12, but we have now studied the Cambridge curriculum. Since we use English, we can practice our English skills too. (P7 Student)

First of all, we are required to learn more, so we have more knowledge than others. And also, we can improve our English skills too. (P8 Student)

Those positive perspectives are in line with the findings of some studies. Suwanarak (2014) discovered that the bilingual education program had positive outcomes. It was helpful in many areas. Her study proved that bilingual education program helped students practiced and improved their English skills. In line with her, SalaberriRamiron and Sánchez-Pérez (2018) found that student's experience in the bilingual class was inspiring because they anticipated opportunities to develop their English language skills from the interaction.

Bilingual education program of dual curriculum in this public senior high school provided additional classes that allowed students to get more profound knowledge. It helped broaden the English proficiency and global horizons about the subject matter in natural sciences both in the 2013 curriculum and Cambridge curriculum. Moreover, the Cambridge certificate that the students will get is beneficial for them to open their pathways to study abroad and joining international competitions.

The findings showed that both teachers and students admitted and believed in this program. Therefore, all the science teachers and most of students showed positive perspectives while being 
asked about their concern of the bilingual education program of dual curriculum they participated in. It can be concluded there were many benefits and strengths of the program for the students, teachers, and even for the school or government to be the reasons for this program to last longer.

\section{Teachers' and Students' Challenges Participating in Bilingual Education Program of Dual Curriculum}

The interview was used as the primary source of collecting the data to answer the second objective of the study: the challenges faced by teachers and students participating in teaching and learning content subjects in a bilingual education program of dual curriculum at the school. In addition, observation was conducted to confirm the interview data.

\section{Teachers' Challenges Teaching Content Subjects in Bilingual Education Program of Dual Curriculum}

Even though all the teachers showed positive perspectives on the implementation of bilingual education of dual curriculum. It does not mean that the teachers did not face any challenges. The interview data showed that the Cambridge science teachers also felt the challenges while participating in the program. The interview data revealed those challenges. First, it was challenging for the additional teachers to be part of the school teachers. Second, it was tough to prepare both curricula. It was so hard teaching different levels with the dual curriculum. Third, teachers learned English in general, but they needed to teach science in English using scientific terms. It was hard to use English in teaching and in preparing the teaching aid. Fourth, language was a big obstacle. The expected results of the recruitment test were not following the student's English skills. Last, it was hard to make the students understand, enjoy, and be motivated. Interview excerpts from the teachers are shown below to support data above.

Ifeel the burden of teaching three levels, especially when processing the students' scores. There is a lot of administration stuff that should be done. Language is a big obstacle. Sometimes the results of the recruitment test are not as expected. What we expect is the students, at least, understand daily English. But apparently not, especially one or two local students from a small city. (PI Teacher)

In the beginning, I suffered a lot to figure out what Cambridge wanted, what K13 wanted. Using English while teaching the students and preparing the teaching aid is also a challenge because we have to make the new teaching aids, like PowerPoint, exercise, worksheet. Besides, finding out the biological terms before teaching was also hard, but I enjoy it now. Then, other challenges are how to make the students understand, enjoy the class, and well-motivated. (P2 Teacher)

It was quite challenging for us, especially for the additional teachers like me. We are not from this school and still young. But now, it is okay. Another challenge is the language because I learned English in general. When I teach physics in English, I should also learn more vocabulary before teaching, just like the students. Explaining the materials in English to the students is also challenging. At first, it was tough to prepare both curricula and to adapt. Now, I feel better and enjoy it. (P3 Teacher) 
The results above showed that teaching in bilingual education program of dual curriculumwas challenging for the science teachers. It was really challenging for the teachers to teach the students science concepts using scientific language. It was not easy at all. Even though the teachers ever joined English courses or had some background in using daily English conversation. It was apparent that explaining the materials using English was also challenging for some other teachers. In line with it, Fitriati (2015) found that teachers struggled to teach English at a senior high school after implementing a bilingual education program.

Similarly, Ma'ruf and Sari (2020) discovered that science and mathematics teachers stated that explaining scientific concepts in English was difficult. So, it is normal for a non-English teacher to find it challenging to teach the students science concepts using English. Language was not only a challenge for teachers to use it while teaching. Besides, it was also hard to explain and make the students understood the science concepts in English. It was because the students' English skills were relatively low. Therefore, the teachers needed to re-explain the concept repeatedly, especially when they decided to use full English. It was just wasted their time since many students did not understand their explanations.

Furthermore, the Cambridge teachers at the school had ever joined the training. At least, they have learned what they should do and know how they should teach the classes of bilingual education program of dual curriculum. They also had English backgrounds such as working with foreigners, having English courses, and teaching general English. It did not mean they did not face any challenges, but at least they were not shy to use English. The observation result showed the same thing that the teachers were so confident talking and explaining using English in front of students. Different from what happened in other studies (Fitri, 2015; Putri, 2010). It was found that the implementation of bilingual education program caused the teachers to struggle. They were burdened with English teaching and learning since they never got any training, special instruction, or exposure to English (Fitri, 2015; Putri, 2010).

All in all, all the science teachers admitted that bilingual education program of dual curriculum has many strengths. Still, they faced some challenges. They realized how beneficial the program was. But they could not deny this program gave a burden on them.

\section{Students' Challenges in Learning Content Subjects in Bilingual Education Program of Dual Curriculum}

It was the same as what had been revealed by the teachers. Students in this study also admitted the strengths of the program. However, they realized that they also faced challenges when participating in the program. They loved to be in the program, but they could not deny that the program put more burdens on them. The interview data showed some challenges faced by the students. First, the main challenge was in terms of English as the language of instruction. For them, the main difficulty was in understanding the terms and concepts of science in English. Second, the condition of studying was twice harder. They had to study extra to cover 2013 curriculum and Cambridge curriculum lessons. The followings are examples of the excerpts from students' statements from the interviews.

In doing assignments or understanding the material, we must understand both Indonesian and English. Because the final exam is in Indonesian, and we learn the subjects using English every day. It has been challenging when the material is being taught in Indonesian. Moreover, if it is being taught in English, it's getting 
more and more difficult. So, the main challenge is the language. It's also about a mental burden. (P1 Student)

The challenge is from the language and the material. Because Cambridge has more materials, and we have to learn from K13 and Cambridge curricula. Sometimes the Cambridge class misses the materials because we have to balance the two materials from the two curricula. That's what makes it difficult because there are more IGCS materials than K13 materials. (P2 Student)

The challenge is I don't understand the materials, and I don't understand English either. (P3 Student)

First is the language. Second, ways of learning are harder. The two curricula are so complicated. (P4 Student)

The main difficulty is in understanding English words, especially in physics. It is my first time hearing words like velocity, acceleration. So, it isn 't easy to understand the terms from the Natural Sciences lessons when explained in English. Then, the condition to study the two curricula twice harder. When the teacher explains the material in English, at night, we have to study extra. It is also a challenge. The main challenge is in terms of language. (P5 Student)

The main challenge is understanding science concepts in English. Sometimes I also feel difficult to learn before and after the class. It means to work harder than regular students. (P6 Student)

The main difficulty is in understanding English for math and natural science concepts. (P7 Student)
The first difficulty is learning time which must be prepared more because the material is more abundant. Then when it comes to language, sometimes I don't understand what it means. (P8 Student)

The results above showed how the students were in burden and faced many challenges while participating in the program. Their main challenge was learning science using English. The students admitted that they had low English skills ability, especially on scientific vocabulary. Therefore, many students wished the teachers to use codeswitching or code-mixing. In other words, they wished teachers to switch from English to Indonesian in a sentence or a conversation when explaining the complicated concepts of science. In line with this, Ariffin and Husin (2011) found that less proficient students in the target language (English) are more forgiving of the teachers' codeswitching than the more fluent category. They believed that their limited command of English had hampered their comprehension, and the teacher should code-switch to help their comprehension. Besides, Tina et al. (2013) discovered that although the students had a positive perspective of English used, they did not comprehend the lessons since they were not used to speaking in English. They were not accustomed to communicate in English.

Jurado and García (2018) also discovered students found it challenging to understand the teacher using English as the teaching language. The students in their study admitted it was hard for them to understand the explanation in English since they had a limited scientific vocabulary, and English for science was new to them. Even though all the participants of this current study admitted that they had joined English courses, participated in bilingual education, loved to watch English movies, and listened to English songs, it was still hard for them to learn science using English thoroughly. In accordance with that, Musmar 
(2018) added that bilingual education program showed its benefits in supporting students; however, it could not be done when students' actual level in English was too low.

Not only language became the challenge, but also the materials that the students had to study. It was hard for them to learn the two curricula because it required more time to learn and covered all 2013 curriculum and Cambridge curriculum materials. It made them had more burdens of managing all the things. Understanding English for science concepts was a challenge even though they loved the program. In line with this, $\mathrm{Li}$ and Wang (2010) also found that students in China highly welcomed the implementation of bilingual education. However, some concerns related to bilingual teaching were also exposed, such as the students relatively had low English skills and lack of English atmosphere.

The results of observation proved how language became the main challenge for students participating in classroom teaching. It could be seen during the observation that the students suffered in learning the science concept in English. Sometimes there were just very few students who responded to the teachers talking in English. Most of the time, they were just quiet when asked whether they understood or not and whether they had questions to ask. But when they were asked in Indonesian, the number of students who responded was much better. It correlated with the language barriers they face. In short, the students in this study admitted they face many challenges while participating, and the main challenge they faced was English usage for the teaching and learning process.

\section{CONCLUSIONS}

The findings of the study demonstrate that all science teachers and most students in this study had positive perspectives and admitted how valuable this program for the students, the teachers, and the school. Second, even though all students and teachers in this study admitted the benefits and strengths of the bilingual education program of dual curriculum, they faced many challenges in participating in the program.

All the samples acknowledged the two main challenges, such as using English as the language of instruction in teaching the students and understanding the teachers' explanation in English. The other one was more preparation and works had been done. It was hard to prepare the teaching aids for the teacher, and it was complicated to learn all the lessons for the students. Even so, all the participants expected this program to last longer with some necessary improvements.

In addition, the school needs to pay more attention to the implementation of the Cambridge curriculum by setting strict regulations about the use of English as the language of instruction and language communication. So, it will be clear for the teachers and students of what language they have to use.

\section{REFERENCES}

Ariffin, K. \& Husin, M. S. (2011). Codeswitching and code-mixing of English and Bahasa Malaysia in content-based classroom: Frequency and attitudes. The Linguistics Journal, 5(1), 220-247.

Baker, C. (2001). Foundations of bilingual education and bilingualism ( $3^{\text {th }}$ ed.). Clevedon, England: Multilingual Matters.

Creswell, J. W., \& Creswell, J. D. (2018). Research design: Qualitative, quantitative, and mixed methods approaches $\left(5^{\text {th }}\right.$ ed.). Thousand Oaks, CA: SAGE.

Fernandez-Costales, A. (2017). Assessing students' perceptions regarding English medium instruction in higher education. Lengua y litertura, 29(2017), 43-63.

Fitriati, S. W. (2015). English bilingual education in an Indonesian public school. In P. A. 
Danaher, P. Redmond, \& J. Lock (Eds.), Educational innovations and contemporary technologies: Enhancing teaching and learning (2nd ed., pp. 87102). London, England: Palgrave Macmillan.

Garcia, O., \& Wei, L. (2015). Translanguaging, bilingualism, and bilingual education. In W. E. Wright, S. Boun \& O. Garcia (Eds.), The handbook of bilingual and multilingual education (1 st ed., pp. 223240). Chichester, England: John Wiley \& Sons.

Heider, F. (1958). The psychology of interpersonal relations $\left(1^{\text {st }}\right.$ ed.). New York, NY: Wiley

Jurado, B. C., \& García, C. M. (2018). Students' attitude and motivation in bilingual education. International Journal of Educational Psychology, 7(3), 317-342.

Lee, S. K. (2006). The Latino students' attitudes, perceptions, and views on bilingual education. Bilingual Research Journal, 30(1), 107-122.

Li, M. (2018). The effectiveness of a bilingual education program at a Chinese university: A case study of social science majors. International Journal of Bilingual Education and Bilingualism, 21(8), 897912.

Li, Y., \& Wang, L. (2010). A survey on bilingual teaching in higher education institute in the northeast of China. Journal of Language Teaching and Research, 1(4), 353- 357.

Lotherington, H. (2004). Bilingual education. In A. Davis, \& C. Elder (Eds.), The handbook of applied linguistics (1st ed., pp. 695-718). Massachusetts, MA: Blackwell Publishing.

Ma'ruf, H., \& Sari, H. Y. (2020). Teachers' perspectives toward the implementation of bilingual immersion program in Indonesian private schools. Journal of English
Education, Literature, and Culture, 5(1), 118-125.

Musmar, R. D. S. (2018). Bilingual education: Between policy and implementation in the United Arab Emirates. Journal of Education in Black Sea Region, 3(2), 63-80.

Noviani., Dahnilsya., \& Novitri. (2018). The teachers' perception on the implementation of bilingual program of SMP and SMA Dharma Yudha Pekanbaru. JOM FKIP, 5(2), 1-11.

Ozfidan, B., Burlbaw, L., \& Kuo, L. J. (2016). Perceptions of an anticipated bilingual education program in Turkey. International Education Studies, 9(10), 174-184.

Putri, V. A. S. (2010). The implementation of bilingualism in the teaching and learning activities at international standardized school (A descriptive qualitative study in $S d$ negeri Sbi Gemolong in the 2009/2010 academic year) (Bachelor Thesis, Sebelas Maret University, Surakarta, Indonesia). Retrieved from https://digilib.uns.ac.id/

Rao, P. S. (2019). The role of English as global language. Research Journal of English, 4(1), 65-79.

Richards, J. C., \& Lockhart, C. (1994). Reflective teaching in second language classrooms. New York, NY: Cambridge University

Salaberri-Ramiro, M. S., \& Sánchez-Pérez, M. D. M. (2018). Motivations of highereducation students to enrol in bilingual courses. Monográfico III, 4(1) 61-74.

Sudiatmika, I. K., Nitiasih, P. K., \& Suarnajaya, I. W. (2017). A case study on the students' and teachers' perceptions on the use of English as medium of instruction and teachers' professional competencies at 
234 | Jurnal Pendidikan Progresif, Vol. 11, No. 2, pp. 219-234, August 2021

SMP Negeri 1 Denpasar. International Journal of Language and Literature, 1(3), 175-183.

Surdyanto, A. (2016). Students' perceptions of the use of English at abilingual setting based on their kindergarten language program. Journal of ELT Research, 1(2), 134-143.

Suwanarak, K. (2014, April 13-15). Bilingual learning and its effects on students' communicative competence. Paper presented at International Academic Conferences on Business, Education and Social Sciences, Vienna, Austria. Retrieved from https://www.westeastinstitute.com/

Taheri, M., \& Heidar, D. M. (2014). An investigation of the effect of bilingual education on language achievement of Iranian pre-intermediate EFL learners. International Journal of Foreign Language Teaching \& Research, 2(7), 30-36.

Tina, M., Zaim, M., \& Syafei, A. F. Z. (2013). Students' perception on the use of English in bilingual class at SMP N 12 X11 Enam Lingkung. Journal of English Language
Teaching, 2(1), 346- 355.

Tong, F., \& Shi, Q. (2012). Chinese-English bilingual education in China: A case study of college science majors. International Journal of Bilingual Education and Bilingualism, 15(2), 165-182.

Tracy, S. J. (2013). Qualitative research methods: Collecting evidence, crafting analysis, communicating impact. (1st ed.). Chichester, England: John Wiley \& Sons.

Undang-undang Republik Indonesia Nomor 20 tentang Sistem Pendidikan Nasional [Law of the Republic of Indonesia Number 20 concerning the National Education System]. 2003. Jakarta: PT Armas Duta Jaya.

Wright, W. E., Boun, S., \& Garcia, O. (2015). Key concepts and issues in bilingual and multilingual education. In W. E. Wright, S. Boun \& O. Garcia (Eds.), The handbook of bilingual and multilingual education ( $1^{\text {st }}$ ed., pp. 1-16). Chichester, England: John Wiley \& Sons. 